\title{
Use of Classification and Pay Plans in Junior College Libraries
}

Dr. Wilson is director of libraries, University of Colorado.

W

HEN I WAS ASKED to discuss the use of classification and pay plans with this group, my first reaction was to wonder just how much junior college librarians were concerned with this subject. This led me to start back through the files of the Junior College Journal. In the November I 948 issue I read with interest the article by Martorana and Koos which reports the findings of an investigation of policies and practices relating to junior college teacher saiaries based upon questionnaires returned by 296 institutions. The concluding observarion of the authors is: "Generalizing from reports from the 296 junior colleges reached in the study, one may conclude that, though considerable evidence of use of sound administrative and personnel practices was discovered, much room for improvement yet remains in the area of salary administration in junior colleges. Strongest point in this regard is the fact that only about half the junior colleges use salary schedules. Effort should be made to determine objectively the factors that ought to be taken into account in a schedule. . . . In addition, all junior colleges should build and adopt a soundly constructed schedule. ... ${ }^{2}$

While this study was limited to salaries

1 Paper presented at the meeting of the Junior College Libraries Section, A.C.R.L., Jan. 20, 1949, Chi-

${ }_{2}^{2}$ Martorana, S. V. and Koos, L. V. "Junior-College Teachers Salaries: Policies and Practices." Junior College Journal XVIII:14I, November 1948. of classroom teachers, implications for librarians contained in the concluding observation of the authors are obvious. As junior colleges build and adopt soundly constructed salary schedules, their librarians should be prepared to participate in determining objectively the factors to be taken into account in such a schedule, at least insofar as library positions are concerned. My impression is that junior college librarians are in a particularly fortunate position in being considered usually as a part of the teaching staff. The standards of the regional accrediting agencies contain such specific statements as: "The librarian should have faculty rank," "The librarian will normally hold academic rank as a member of the faculty," "The librarian should be a full-time library employee, have a degree in library science, and have faculty rank," or "The librarian should have faculty rank and salary status."

As I proceeded through back issues of the Junior College Journal I arrived at the December 1947 issue which contained Dr. B. Lamar Johnson's article, "JuniorCollege Library Problems," a report of a study made by a special library committee which sought to determine what problems relating to the junior college library are in greatest need of investigation. Nineteen problems were listed, were judged by librarians and administrators and were ranked on basis of importance for early investigation. Of the 19 problems, three are closely related to or would involve the use of classification and pay plans in any 
investigation. These three problems are: $\mathbf{I}$. Salaries of librarians; 2 . Criteria for preparation of librarians; 3. Criteria for determining number on library staff. The first of these problems was ranked 5 by all librarians and 5.5 by administrators. The second was ranked 9 by all librarians, Io by librarians in 39 large colleges, and I 5.5 by administrators in the same colleges. The third was ranked II by all librarians, $\mathrm{I} 6$ by librarians and $\mathrm{I} 2$ by administrators in the group of 39 large colleges. It is interesting to note that this third problem was ranked 13.5 by librarians from small colleges (by definition in this study those with enrolments of 300 or fewer) and 9 by librarians from colleges with enrolments of more than 300 to make up the total rank of II. The reason for this difference in rank assigned this problem by the small and by the large colleges is sufficiently obvious to require no comment.

While these problems which would involve classification and pay plans do not rank at the top, they do rank sufficiently above the median to justify the conclusion that they merit the attention of this group and should be investigated.

Before considering the question of classification and pay plans in junior college libraries may I review with you certain factors which should be kept in mind. An analysis of the Junior College Directory, 1948 reveals that of the entire group of junior colleges, 49 per cent are publicly controlled institutions, while $5 \mathrm{I}$ per cent are under private control. The past few years have seen a definite trend toward an increase in the percentage of publicly controlled junior colleges. I think it is safe to state that classification and pay plans are more likely to be put into effect in publicly controlled institutions, perhaps as a form of civil service, than in those which are privately controlled.

A second factor to be kept in mind is the size of the 663 junior colleges for which enrolments are reported in the 1948 directory. The average enrolment for all colleges is 686 , but the median enrolment, which is more significant for our purposes, is less than 300. Nineteen per cent of the junior colleges have an enrolment of less than 100,40 per cent have less than 200 , 54 per cent have less than 300 , and 65 per cent have less than 400 . Only I 8 per cent have enrolments of more than 1000 , which means that there are more junior colleges with enrolments of less than Ioo than with enrolments of more than Iooo.

The third factor is the size of staffs in junior college libraries. In Part II of American Junior Colleges, second edition, I 948 , institutional information is supplied by 564 junior colleges that are accredited or have received equivalent recognition by national, regional or state agencies whose function it is to pass upon the standards and quality of work of these institutions. A check of information in regard to the number of library staffs supplied by these junior colleges reveals some interesting figures. Only six per cent report a staff of three or more full-time librarians, nine per cent report two full-time librarians, 55 per cent report one full-time librarian, and 30 per cent indicate part time or no librarians. The statement of the chief of the A.L.A. Office of Personnel Administration that "Even the small library with a staff of less than five will gain by having its personnel policies and procedures established and known," ${ }^{3}$ applies to 98 per cent of junior college libraries.

Interest of librarians in well-considered classification and pay plans, developed in the light of the library's special needs and modern classification principles, is not a new thing. The history of the development of such systems and their value to

${ }^{3}$ Timmerman, H. B, "Staff Shortages and Sala. ries." A.L.A.'Bulletin 41 :102, April 1947 . 
libraries was described as far back as 1936 in an article in the Library Journal by Eleanor Hitt. ${ }^{4}$ The federal government reclassified the entire library service in 1924. Classification and pay plans for the municipal libraries of California were developed by the California Library Association in 1934, and in 1936 New Jersey adopted a "Suggested classification of library positions in municipal libraries in New Jersey." Other state library associations have adopted classification schemes during the past io years.

The American Library Association has been working on classification and pay plans for libraries for a number of years. In 1927 the report of the Bureau of Public Personnel Administration to the A.L.A. Committee on the Classification of Library Personnel was issued under the title Proposed Classification and Compensation Plans for Library Positions, often referred to as the Telford report. In 1929 a subcommittee of the A.L.A. Committee on the Classification of Library Personnel brought out Budgets, Classification and Compensation Plans for University and College Libraries which superseded that part of the Telford report which dealt with colleges and universities.

The A.L.A. Board on Salaries, Staff, and Tenure published Classification and Pay Plans for Municipal Public Libraries in 1939 as its first contribution to the series of classification and pay plans for all types of libraries which it planned to issue to fulfil one of the functions assigned it by the A.L.A. Council.

In the spring of 1939 the Association of College and Reference Libraries, which was then a section and is now a division of the A.L.A., appointed a Committee on Budgets, Compensation and Schemes of Service, and in June 1939 the A.L.A.

"Hitt, Eleanor. "Advantages of a Classified Service in Libraries." Library Journal 6r:663-66, Sept. 15, r 936 .
Board on Salaries, Staff and Tenure appointed its Subcommittee on Budgets, Compensation and Schemes of Service for Libraries Connected with Universities, Colleges, and Teacher Training Institutions. The membership of the committee of the A.C.R.L. and of the subcommittee of the board was identical. Mary Vick Burney, librarian of the University of Tennessee Junior College Library, represented the interests of junior colleges on this committee from its beginning in 1939.

After four years of intensive work by the committee, the A.L.A. published in I943 three volumes of Classification and Pay Plans for Libraries in Institutions of Higher Education. The first volume in the series was designed for non-degree-conferring institutions, which by definition included junior colleges, two-year and threeyear normal and teacher training institutions, and technical institutions above the high school level that do not confer a bachelor's or higher degree. Editorial work on the second edition of this series was completed late in 1947 and it was issued in January 1948.

The A.L.A. Board on Personnel Administration, which replaced the Board on Salaries, Staff and Tenure, issued the following statement in 1947 in setting up a four year goal:

"The service a library renders to any community or institution is in direct relation to the quality of its personnel and the conditions of employment, work environment and welfare under which the library staff performs its functions.

"The Board on Personnel Administration has, therefore, set as its four year goal the development of effective programs of personnel administration in libraries. Particular emphasis will be placed on: $\mathrm{I}$. Establishment of sound position-classification plans; 2. Provision of adequate salary budgets, development of equitable salary 
schedules, and improvement of salaries at all levels; 3 . Analysis of duties performed in various positions to assure effective utilization of personnel by making proper distinction between professional and nonprofessional positions and between various levels of duties in all services; 4. Adoption of satisfactory provisions affecting employment, work environment, and welfare."

Since that time the board has made substantial progress toward the achievement of these goals by holding institutes in personnel administration, by conducting and sponsoring studies, surveys, and research, by preparing publications illustrating the application of sound principles of personnel management to libraries and by using promotion, education and other media to assist librarians in obtaining these objectives.

I have already mentioned the second edition of Classification and Pay Plans for Libraries in Institutions of Higher Education which was issued in January 1948. The board proposed "Minimum Library Salary Standards for 1948" which were adopted by A.L.A. Council in January 1948, and an article by the board chairman explaining the new standards appeared in the A.L.A. Bulletin for March 1948. A symposium on library salaries sponsored by the board appeared in the A.L.A. Bulletin for April 1948. "Library SalariesPresent and Future" was the subject of an open discussion meeting sponsored by the board at the Atlantic City Conference in June 1948 and reported in the A.L.A.Bulletin for July-August 1948. The board has cooperated with the U.S. Bureau of Labor Statistics in making a survey of salaries and working conditions of library personnel. A major contribution to the study of efficient personnel utilization has been made by the board's Subcommittee on Analysis of Library Duties with the publication of Descriptive List of Professional and Nonprofessional Duties in Libraries.
In an effort to assist libraries in making classification studies the board appointed a Subcommittee on Job Analysis Manual and Classification Pay Plan Manual. This subcommittee is preparing a manual which describes step by step the way a job analysis is made and how a classification and pay plan is prepared, implemented and administered. A second draft has been sent to librarians and personnel experts for criticism, and it is expected that final publication will appear this year.

Keeping in mind this rather extensive background which I have sketched for you let us now consider the question of the use which can be made of classification and pay plans in junior college libraries, assuming agreement upon the principle that a classification and pay plan is desirable for every library, regardless of the size of its staff.

The first point to keep in mind, and a very important one, is that the individual library must make its own classification and pay plan to fit its own specific situation. No national pattern can be drawn up which will fit any library without modification and adaptation. The classification plan of the individual library may follow the national pattern in certain respects but will differ in others. It will and should fit the specific library only. Its classes of positions may be fewer than those in the national model. Certain positions may combine duties of two or three of the sample class specifications and other positions which do not appear in the sample specifications. The classes of positions recognized and the duties and responsibilities of these positions will vary to meet the local situation.

Four steps which should be followed by a library in drawing up a classification and pay plan of its own are: $\mathrm{I}$. Study the principles of position classification and salary determination; 2. Make a job analysis of each of its positions; 3. Develop its own position 
classification plan based on the job analysis; 4. Prepare a pay plan based on the position-classification plan.

The first step is simply a matter of in-service training of the junior college librarian in the principles of position classification. Thorough study of various tools and sample plans such as those made available by the Board on Personnel Administration, and of articles on position classification in library periodicals and references on job analysis in industry, should provide the understanding necessary before the final three steps are undertaken.

A job analysis of each position in the library is the base upon which any classification plan is developed. In a scientific analysis, a record of activities is kept for days or weeks with the exact amount of time spent on each. This type of analysis is essential when any large group of positions is to be classified. In the case of junior college libraries, when 85 per cent report one full-time librarian or less, such an exact record may not be necessary. The librarian probably can set down a record of activities and time spent on each which will be adequate as a job analysis. A more exact analysis may, however, prove to be very worthwhile. A more significant portion of the librarian's time may be spent in nonprofessional work than is realized until an exact and accurate time study reveals a situation which the librarian will wish to correct.

The A.L.A. Fourth Activities Committee recently completed a minute by minute time study of each member of the A.L.A. Headquarters staff for two training periods and then for a full week. The detailed time studies of the seven staff members who provide the professional services at headquarters showed that approximately 60 per cent of their time was spent on clerical and administrative tasks and that only about one-third of their time was devoted to anything that can be construed as professional service. The actual percentages of time spent on administrative and clerical work were $53,53,60,64,64,76$, and 90.

For the 15 per cent of junior college libraries which have two or more full-time librarians at least a questionnaire form of job analysis should be made. This questionnaire would have as its main body a statement of duties, a listing of individual tasks with an approximate percentage of time spent on each. The staff members would list regular and most important tasks first, and indicate the irregular or emergency duties. From these completed forms the librarians in junior college libraries with a staff of less than five would write job descriptions for each position. In the two per cent of junior college libraries which have five or more library staff members, a staff committee might be advisable for preparing job descriptions and proceeding with the development of the classification and pay plan.

A position classification plan based on the completed job analysis is simply the grouping into classes on the basis of duties and responsibilities of the various positions of a given institution. Classification must be based on those characteristics which make positions similar or dissimilar from the standpoint of: The duties and responsibilities of the position; the qualifications required to fill them; and salaries. In libraries where the staff numbers two or less, this grouping of positions is no problem, and it should present no serious difficulties to those librarians of junior college libraries with staffs of three or more members.

After the position classification plan is made the pay plan can then be developed. The pay plan for the individual library should be developed with the following considerations in mind: The salaries paid the faculty and clerical staff of the institution; the cost of living in the particular community; the compensation paid in 
libraries in other junior colleges which are considered comparable because of like situations and conditions; the compensation paid for work performed in comparable professions where duties and responsibilities are of equal weight.

In developing the pay plan, in addition to the above considerations the "Minimum library salary standards for 1948 " adopted by the A.L.A. Council Jan. 31, 1948, should be kept in mind and should form the basis for a pay plan for junior college libraries.

If you will permit me to attempt a brief summary of the place of classification and pay plans in junior college libraries it will be the following: Because of the size of the staffs of junior college libraries, problems of effective personnel administration in the libraries will be on a small scale and usually on a personal basis, but will be of as great importance to the junior college as are large scale problems in the largest libraries to their parent institutions. Consequently a junior college library classification and pay plan which may require only one or two pages for presentation is as significant and of as much importance in its place as is the 576-page classification and pay plan of the Library of Congress.

\section{Catalogs, Codes and Bibliographical Control}

\section{(Continued from page 40o)}

raphers must make them arbitrarily, and in a few decades they might well prove something of a blessing. It is not so much because the present is too much with us as because it is always with us that there is urgent need for some sort of decision along the lines I have indicated.

While a similar problem confronts those responsible for the catalogs of large libraries, it is more complicated. Books are likely to be stored at a distance because of infrequency of use. This will be closely related to age, but much current material will also be so stored. Rare books, on the other hand, are likely to be kept near the heart of the library, for safety and display if not for use. A library like Harvard's could print an author catalog of its present holdings from cards withdrawn from the catalog. The cards need not be reinserted. The accumulation of arrears and the continuing purchase of old works would mean that the card catalog would not be limited to entries for works published after a certain date, and that the printed catalog would not contain entries for all works before a certain date. The size of card catalogs may be attacked quite differently, and has already received much thought and some action.

In conclusion I should like to repeat that if bibliographical control is to wait on uniformity in cataloging codes it will not be achieved. The Prussian Instructions are not likely to be adopted in this country nor the Anglo-American Code in Germany, nor is a middle way acceptable to both countries probable. What we can look for, however, is that countries at present bibliographically unorganized will learn the methods of those that are comparatively advanced, so that diversity will not increase. Much might be done by what might be called the peaceful penetration of librarians and librarianship. American influence in the Vatican Library and its code, and in many lands by the distribution of Library of Congress cards, show what can be achieved. As for the question of control by periods, we would probably be thought for a time to be wanting in a sense of historical perspective. Our actions would in fact be based on a true appreciation of the needs of the future as well as on a realization of the importance of the present and the past. 